\title{
LYME BORRELIOSIS IN NORTH BACKA DISTRICT
}

\author{
Dragica Kovačević Berićlæ, Tibor Molnar ${ }^{2}$, Morana Miković ${ }^{1}$, Sara Savić ${ }^{3}$ \\ ${ }^{1}$ Public Health Institute Subotica, Subotica, Republic of Serbia \\ ${ }^{2}$ Veterinary Specialist Institute "Subotica", Subotica, Republic of Serbia \\ ${ }^{3}$ Scientific Veterinary Institute "Novi Sad", Novi Sad, Republic of Serbia
}

\section{Abstract}

Lyme disease is the most common vector borne disease in regions with moderate climate. The cause of the disease is Borrelia burgdorferi sensu lato (B. burgdorferi s.l.), whereas infection is spread via bite from a tick carrying the causative agent. The objective of this work is the examination of descriptive-epidemiological characteristics of Lyme disease in North Backa region in the period from 2012 to 2016. In terms of classification, Lyme disease does not fall into the category of diseases that must be reported when infection occurs among animals. The average rate of incidence in humans during the observed five-year period is $7 / 100.000$. The highest incidence of this disease among humans was observed in 2013 (In 12.2/100,000) with 22 reported cases, whereas the lowest incidence was in 2015 (In 5.0/100,000) with 9 reported cases. The highest rate of incidence was recorded in Bačka Topola municipality - 15.9/100.000; followed by Mali Iđoš with 7.2/100.000; while the lowest rate was recorded in Subotica being 5.0 cases per 100,000 residents. The presence of the disease was confirmed in all patients via laboratory (serological) tests. Women were more likely to become infected, with the male-female patient ratio being $41 \%-59 \%$. The disease was documented predominantly among people aged 50-69. The majority of cases were recorded during spring and summer, in the period from May to June (71\%). Among animals, the disease was documented in Subotica and Mali Iđoš municipality, with average prevalence rates among dogs and horses being $0.07 \%$; and $1.52 \%$ respectively. Subotica municipality has the most accurate records of cases and a prevalence of $0.06 \%$ among dogs, and $1.43 \%$ among horses, while Mali Iđoš municipality has higher prevalence, being $2.99 \%$ among horses and $0.14 \%$ among dogs. The highest occurrence of Lyme dis-

${ }^{1 *}$ Corresponding author: dberic65@yahoo.com 
ease among animals was documented in 2015, with a prevalence of $2.85 \%$ among horses. The presence of causative agents among examined ticks in Mali Iđoš municipality was $16.28 \%$ on average, predominantly in 2015 (in $21.21 \%$ of examined ticks).

Keywords: Lyme disease, incidence, sub-registration, prevalence, horses, dogs, ticks

\title{
LAJM BORELIOZA U SEVERNOBAČKOM OKRUGU
}

\author{
Dragica Kovačević Berić ${ }^{1 \star}$, Tibor Molnar ${ }^{2}$, Morana Miković ${ }^{1}$, Sara Savić ${ }^{3}$ \\ ${ }^{1}$ Zavod za javno zdravlje Subotica, Subotica, Republika Srbija \\ ${ }^{2}$ Veterinarski specijalistički institut "Subotica”, Subotica, Republika Srbija \\ ${ }^{3}$ Naučni institut za veterinarstvo "Novi Sad”, Novi Sad, Republika Srbija
}

\section{Kratak sadržaj}

Lajmska bolest je najčešća vektorska bolest u područjima sa umerenom klimom. Uzročnik bolesti je Borrelia burgdorferi sensu lato (B burgdorferi s.l.), a infekcija se ostvaruje ubodom zaraženog krpelja. Cilj rada je sagledati deskriptivno-epidemiološke karakteristike lajmske bolesti u Severnobačkom okrugu u periodu od 2012-2016.godine. Kod životinja, oboljenje ne podleže obavezi prijavljivanja. U posmatranom petogodišnjem periodu registruje se prosečna stopa incidencije od 7/100 000. Najviša incidencija ovog oboljenja registrovana je 2013. godine (In 12.2 / 100 000), kada su prijavljene 22 obolele osobe, a najniža 2015 (In 5.0 / 100000 ), sa registrovanih 9 slučajeva ovog oboljenja. Najviša prosečna stopa incidencije registrovana je u opštini Bačka Topola 15.9 / 100000, sledi opština Mali Iđoš sa 7.2 / 100000 i najniža u opštini Subotica, 5.0 / 100000 stanovnika. Svi oboleli su imali laboratorijsku (serološku) potvrdu bolesti. Češće su oboljevale žene, u odnosu Ž:M 59\% - 41\%. Oboljenje je najčešće registrovano u uzrastu od 50-69 godina. Većina slučajeva zabeležena je u prolećnim i letnjim mesecima u periodu od maja do jula (71\%). Kod životinja oboljenje je registrovano u opštinama Subotica i Mali Iđoš, kod pasa sa prosečnom godišnjom prevalencom 0,07\%, i konja 1,52\%. Prevalenca u opštini Subotica kod pasa je $0,06 \%$, kod konja 1,43\%. Najviše obolelih životinja registrovano je 2015.godine, sa prevalencom od 2,85\% kod konja. Iz ispitanih 
krpelja u Opštini Mali Iđoš prisustvo uzročnika je utvrđeno prosečno u 16,28\% ispitanih krpelja uzetih sa ljudi i / ili životinja, najviše tokom 2015 (21,21\% pregledanih krpelja).

Ključne reči: Lajmska bolest, incidencija, subregistracija, prevalenca, konji, psi, krpelji

\section{INRODUCTION}

Lyme disease is the most frequent vector borne disease in the regions with moderate climate. Causative agent of the disease is Borrelia burgdorferi sensu lato complex, from the family of Spirochaetacea. Within this complex, there are several borrelia genotypes, but for some of them, their pathogenicity for humans and / or animals has still not been determined. In Europe, Lyme borreliosis is caused by three similar Borrelia types: B. burgdorferi sensu strico, B.garinii and B. afzelii (Margos et al., 2008). The disease is transmitted by the Ixodide ticks. In the USA, the major vectors are Ixodes scapularis and Ixodes pacificus, in Europe Ixodes ricinus and in Asia Ixodes persulcatus (Gray, 1998, Steere et al., 2004). Global geographical distribution of Lyme disease is in correlation with the prevalence of Ixodide ticks infected with Borrelia burgdorferi. Mice and mice-like rodents are considered as the major reservoirs of infection even though the disease has been found in many animal species so far (Pavlović et al., 2006).

In humans, this disease is manifested with a broad spectrum of clinical symptoms, with sub acute, acute or chronic form of the disease. Some of them are very characteristic (erythema migrans), so that with the history of tick bite it is sufficient to establish the diagnosis. The conformation of other forms of the disease requires identification of the causative agent or specific antibodies. In the initial stage of the disease, one third or half of the infected people give seropositive response. In later stages of the disease seropositivity increases to 90-100\% (Aguero-Rosenfeld et al., 2005). Besides in humans, Lyme disease can be found in dogs, horses, cattle and sheep (Infectious diseases in Province of Vojvodina in 2015, annual report; Mladenović 2014.).

In Serbia first studies on Lyme disease were started in 1987. In the region of North Bačka Lyme borreliosis was firstly found in 1994.

There were two main aims of the study. The first aim of the study was to survey the descriptive epidemiological characteristics of Lyme disease in North Bačka region during the period from 2012 to 2016. The second one 
was to collect and analyse epizootiological characteristics of Lyme disease in animals of North Bačka County in the time frame from 2012 to 2016. This was shown with the following data:

- Number of confirmed clinical cases in dogs and horses,

- Study on infection in ticks.

\section{MATERIAL AND METHODS}

In this study, a descriptive epidemiological method was used. The source of the information and data were health reports for infectious disease. The indicators of frequency of Lyme disease occurrence was the ratio of proportion and rate.

The source of data in animals was the database of confirmed clinical cases of Lyme disease in daily protocols of veterinary practices from North Bačka District during the period from 2012 - 2016, as well as laboratory reports of the Specialist Veterinary Institute of „Subotica“ and Scientific veterinary institute „Novi Sad“ (used for confirmation of clinical diagnosis).

The prevalence of the disease was expressed in relation to the number of registered dogs or horses at the level of a municipality. Data on findings in tick samples collected from people and animals were from the municipality of Mali Iđoš, taken from the archives of Veterinary Practice „Anidok“.

Diagnosis of Lyme disease in dogs and horses was established based on the anamnesis, epidemiological data on the exposure of sick animal to a tick bite, clinical signs in horses and dogs (fever, arthritis, lameness, joint oedema, etc) and a positive reaction to a specific antibiotic treatment (tetracycline, doxycycline). Laboratory confirmation of clinical diagnosis (3-6 weeks after infection) was done using several methods.

In dogs: with commercial fast serological tests for the detection of C6 antibodies

- CaniV-4 (Bionote); Se:93\%, Sp: 98\%, or

- $\quad$ SNAP 4Dx (Idexx); Se:94\%, Sp:96\%

In horses, the conformation of clinical diagnosis was done using IgG ELISA test.

The ticks collected from humans and animals were examined only upon the demand of the owner in the region of Mali Idjoš, applying Fassisi ${ }^{\oplus}$ BoTick membran immunoassay fast test for a direct confirmation of the causative agent in a tick. 
The abdominal content of free ticks collected from near neighbouring municipalities - Ada, Novi Bečej and Novi Sad, was examined by dark field microscopy. From ticks that were identified as positive for the presence of $B$. burgdorferi s.l spirochaetae, cultivation was performed in commercial media (BSK-H Medium Complete, Sigma) (Cutler et al., 2017).

\section{RESULTS}

During the study period, 73 cases of Lyme disease were registered in humans in North Bačka District, with an average incidence of 7.8/100000. The highest incidence of this disease was registered in 2013, (Incidence 12.2/100000) when 22 sick persons were reported, and the lowest incidence was in 2015 (Incidence 5.0/100000), with only 9 registered cases of Lyme disease in humans (Graph 1).

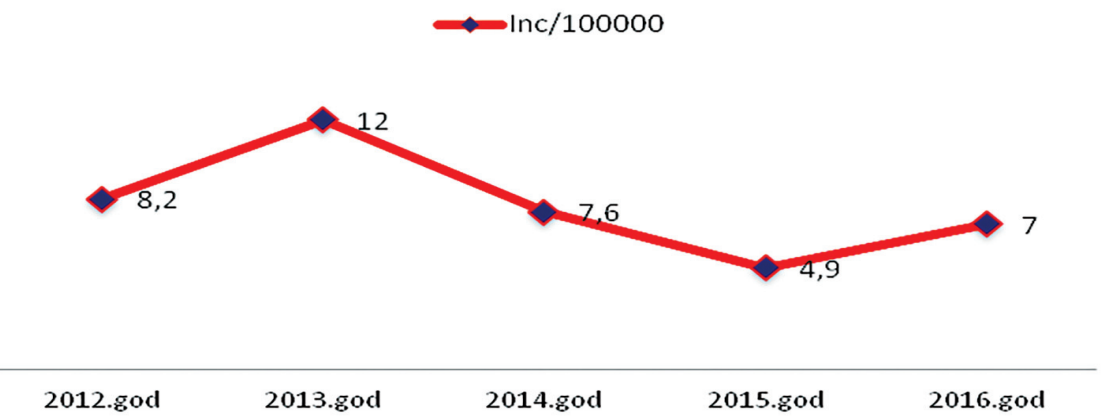

Graph 1. Lyme disease incidence in North Bačka District from years 2012 - 2016

During the period of study, the disease was registered in all three municipalities of the North Bačka District. The highest average level of incidence was found in the municipality of Bačka Topola (15.9/100000), then in municipality of Mali Iđoš $(7.2 / 100000)$ and the lowest one was in the municipality of Subotica $(5.0 / 100000)$.

Table 1. Geographical distribution of Lyme disease in North Bačka District from 2012-2016

\begin{tabular}{|l|c|c|}
\hline Municipality & Number of sick people & Average incidence/100000 \\
\hline Subotica & 39 & 5 \\
\hline Bačka Topola & 29 & 15.9 \\
\hline Mali Iđoš & 5 & 7.2 \\
\hline Total & 73 & 7.8 \\
\hline
\end{tabular}


During the study period, 43 of the patients with Lyme disease were females (Inc 8.8/100000) and 30 were male (Inc 6.8/100000)

The graph showing age specific levels of incidence has a bimodal shape. The highest age specific incidence was found in children (0-9 years), but also in older population (in sixth and seventh decade of life).

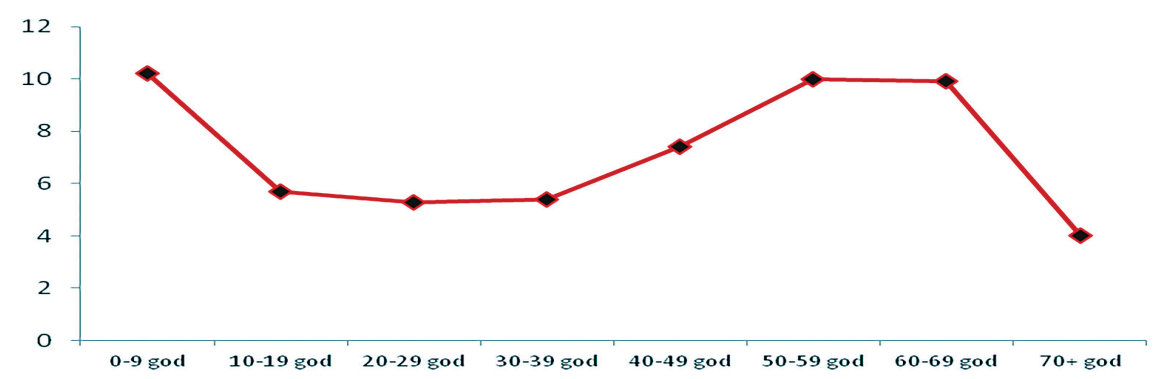

Graph 2. Age specific incidence levels in Lyme disease.

Lyme disease has a characteristic seasonal distribution. The highest number of cases (71\%) is registered in spring and summer months, from May to July, or more specifically during the period of six months, from May to October, (even $90 \%$ of all reported cases are Lyme disease) (Graph 3).

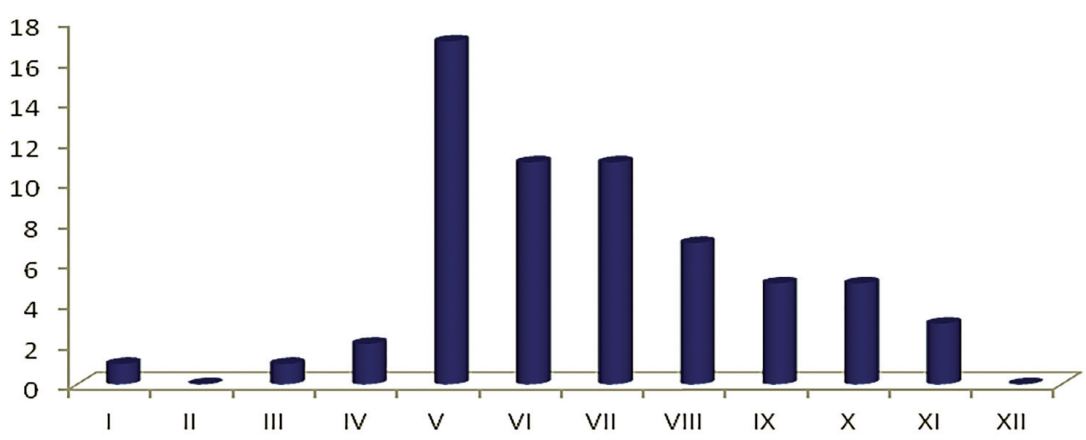

Graph 3. Distribution of Lyme disease patients in months. 


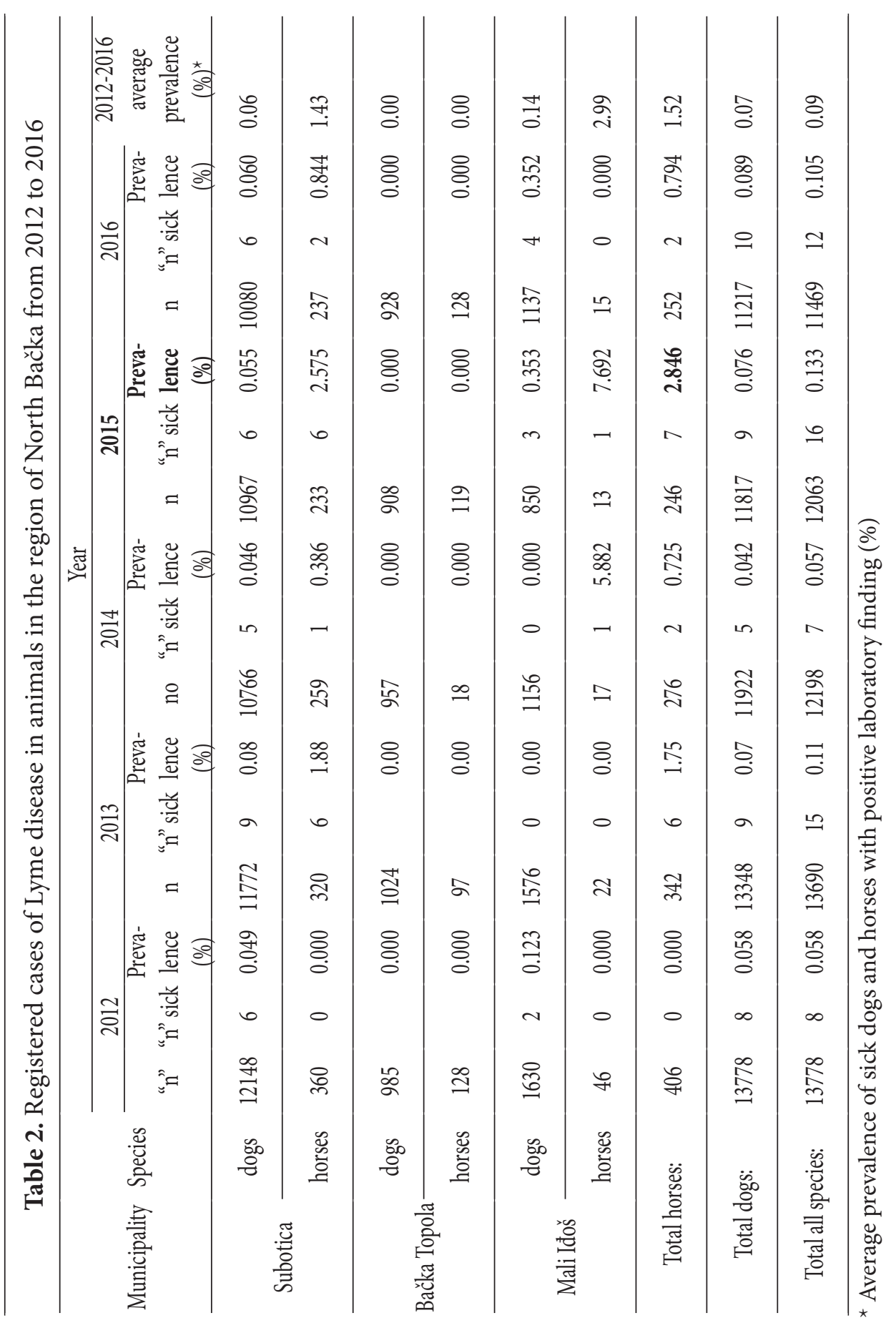




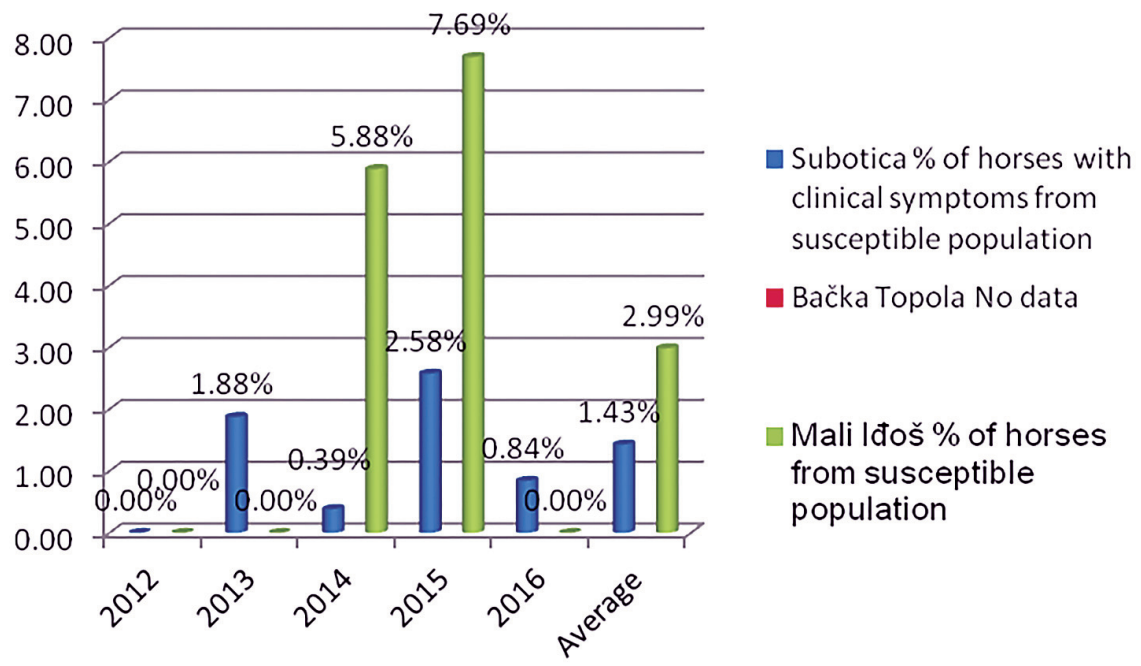

Graph 4. Results of the study on prevalence of borreliosis in dogs, by the municipalities of North Bačka District

During the study period from 2012-2016, in the municipalities of North Bačka region, human cases of Lyme borreliosis were registered with the average incidence rate of 7.8/100000. The highest incidence has been registered in 2013 (In 12.2 / 100000), when there were 22 human cases of the disease reported and the lowest incidence was in 2015 (In 5.0 / 100000), with 9 registered cases of human borreliosis (Graph 1). 
Table 3. The average number of registered Lyme disease cases in animals in North Bačka District for the period 2012-2016

\begin{tabular}{|c|c|c|c|c|}
\hline Municipality & Species & $\begin{array}{c}\text { Average } \\
\text { number of } \\
\text { animals }\end{array}$ & $\begin{array}{c}\text { Average } \\
\text { number } \\
\text { of registered } \\
\text { sick animals }\end{array}$ & $\begin{array}{l}\text { Average prevalence } \\
\text { from 2012-2016, } \\
\text { in dogs and horses, } \\
\text { confirmed with labo- } \\
\text { ratory finding (\%) }\end{array}$ \\
\hline \multirow{2}{*}{ Subotica } & Dogs & 9130.6 & 5.2 & 0.06 \\
\hline & Horses & 234.4 & 2.6 & 1.43 \\
\hline \multirow{2}{*}{ Bačka Topola } & Dogs & 774.8 & 0 & \multirow{2}{*}{ No data } \\
\hline & Horses & 72.4 & 0 & \\
\hline \multirow{2}{*}{ Mali Iđoš } & Dogs & 1042.4 & 1 & 0.14 \\
\hline & Horses & 19.6 & 0.4 & 2.99 \\
\hline \multicolumn{2}{|c|}{ Total for horses: } & & & 1.52 \\
\hline \multicolumn{2}{|l|}{ Total for dogs: } & & & 0.07 \\
\hline \multicolumn{2}{|l|}{$\begin{array}{l}\text { Total for dogs } \\
\text { and horses: }\end{array}$} & & & $0.09 \%(9 / 10.000)$ \\
\hline
\end{tabular}

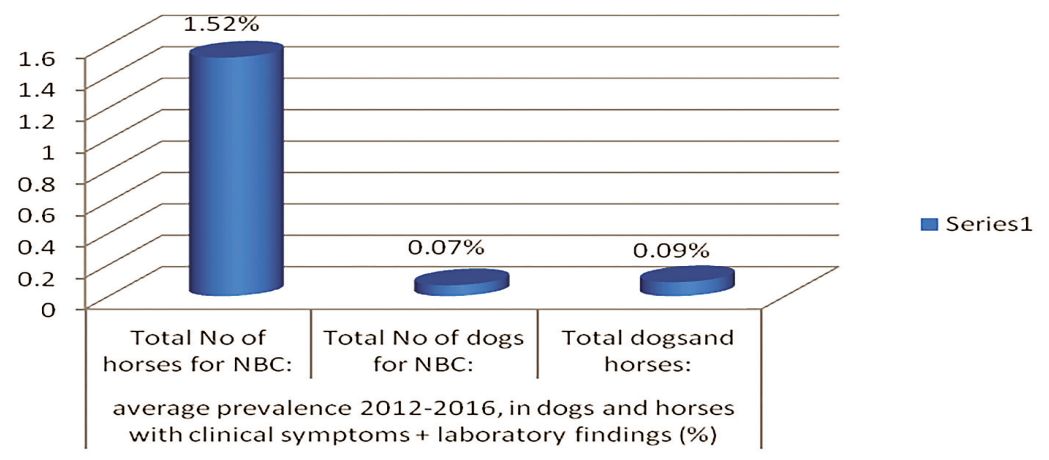

Graph 6. The average number of registered animal cases of Lyme borreliosis in the region of North Bačka District during the period 2012-2016 
Findings on the presence of causative agent of Lyme disease in ticks on the territory of Mali Iđoš municipality obtained using Fassisi ${ }^{\circledast}$ BoTick membran immunoassay are shown in Table 4.

Table 4. Findings on the presence of causative agent of Lyme disease in ticks on the territory of Mali Iđoš municipality (Fassisi ${ }^{\ominus}$ BoTick membran immunoassay)

\begin{tabular}{lcccccc}
\hline \multicolumn{1}{c}{ Year: } & 2012 & 2013 & 2014 & $\mathbf{2 0 1 5}$ & 2016 & Average \\
$\begin{array}{l}\text { No. of ana- } \\
\text { lysed ticks }\end{array}$ & 26 & 30 & 40 & 33 & & $\mathbf{3 2 . 2 5}$ \\
$\begin{array}{l}\text { No. of positive } \\
\begin{array}{l}\text { \% ticks positive for } \\
\text { B. burgdorferi s.l. }\end{array}\end{array}$ & 2 & 4 & 8 & 7 & $\begin{array}{c}\text { Not ana- } \\
\text { lysed }\end{array}$ & $\mathbf{5 . 2 5}$ \\
\hline
\end{tabular}

There are no data on planned sampling of ticks from urban green areas in any of the municipalities in North Bačka region. The number of analysed I.ricinus ticks, positive for the presence of B. burgdorferi s.l. has been compared to the previously reported results from the near neighbouring regions. In those regions, the analysis was done by dark field microscopy examination of abdominal content of live ticks (Table 5).

Table 5: Comparison with near neighbouring regions (Mali Iđoš = 16.28\%)

Number of analysed and positive ticks I. ricinus for the presence of B. burgdorferi in different regions during 2008 (Savić et al.)

Region

Total No of No of ticks positive examined $I$. for the presence of ricinus ticks
$\%$ of ticks positive for the presence of $B$. burgdorferi s.l.

Region Ada

$-\mathrm{Mol}$

Region Novi

Bečej

Region of Novi

Sad city with 


\section{DISCUSSION}

Global geographic distribution of Lyme disease is in correlation with the spreading of Ixodes ticks. Infection foci can be found in the regions with moderate climate which fits the biological cycle of this vector.

During the study period 2012- 2016, 73 human cases of Lyme disease were registered in North Bačka region, with an average annual incidence of 7.8/100000. The highest incidence of this disease was found in 2013 (In 12.2/100000), when 22 sick persons were registered, while the lowest incidence was found in 2015 (In 5.0 /100000), with 9 registered cases of human Lyme disease. During the period of study, the disease was registered in all three municipalities of North Bačka region. The highest average incidence was found in Bačka Topola municipality (In 15.9/100000), than in municipality of Mali Iđoš (In 7,2/100.000) and Subotica where the average incidence found was $5.0 / 100000$ residents.

At the same time, in the Republic of Serbia and Vojvodina, average annual incidences were 11.3/100000 and 9.9/100000 residents respectively (Infectious diseases in AP Vojvodina 2015, the annual report). In whole Europe, 85.000 cases of human Lyme disease are registered annually. It is estimated that significant number of Lyme disease cases pass unrecognized and unregistered. Significantly high incidence is registered in Austria (300/100000) and Slovenia (155/100000), and the lowest incidence can be found in Great Britain (0.7/100000) and Ireland (0.6/100000) (Orloski, 2000; Rizzoli, 2011). Many experts support the opinion that a significant number of cases remain unreported and unregistered, and some of them even estimate that the real incidence is 2-3 times higher than the one officially reported (Ropac et al., 2013).

These big differences in the incidence confirm that Lyme disease keeps the well-known focal distribution on large continental levels, as well as in small countries, to the level of region and municipalities, which is caused by the distribution of vectors. In our study we have also confirmed that three times higher incidence was found in the municipality of Bačka Topola as compared to Subotica.

Out of the total number of cases of human Lyme disease, females were more infected than males 43:30 (1.33:1). Most of the authors have established similar gender distribution among infected persons (Pavlović et al., 2006; Infectious diseases of AP Vojvodina, the 2015 annual report 10). On the contrary, some authors such as Ropac et al, have found three times higher incidence of the disease in men as compared to woman e.g., in Bjelovarsko-Bilogorska County in Croatia (Ropac et al., 2013). 
The disease has been registered in all age groups and the most age specific rates can be found in children (0-9 years) as well as in the elderly group (sixth and seventh decade of life). Distribution of the disease by age group is bimodal like in most of the countries, where the primary (lower) maximum is found in children from 5-9 years old and secondary (higher) maximum in adults from 50-64 years old (Infectious diseases in AP Vojvodina 2015, annual report). The explanation of these differences in disease occurrence among different age groups can be associated with specific activities and behaviour of these groups during their free time outside (Mladenović, 2014).

Lyme disease (Erythema migrans) has a characteristic seasonal distribution. The highest percentage of cases (71\%) is registered during the spring and summer months, from May to July. The increase in number of sick people is superposed with seasonal activity of ticks and more frequent stay of the people outside. Therefore, this disease has a seasonal character in all regions with continental climate. The majority of the quoted authors have come to the same results in their research (Pavlović et al., 2006; Infectious diseases of AP Vojvodina 2015, the annual report; Ropac et al., 2013).

\section{CONCLUSION}

Based on the findings obtained during the study period 2012 - 2016, in the region of North Backa District, the number of registered human cases of Lyme disease shows a decreasing tendency. Significant differences in incidence rates were found between different municipalities and also large oscillations in number of registered cases per year are most probably due to miss registration of cases and failures in reporting to the relevant public health authorities or epidemiological competent services and less likely, to improved epidemiologi$\mathrm{cal}$ situation. The possible reasons for failures in reporting cases may vary, but some of them certainly include omissions in keeping records, ineffectiveness of laboratory diagnostic etc. Regarding the prevalence of registered clinical cases, it can be assumed that large number of unexamined dogs and horses is seropositive and pass undiagnosed as subclinical cases.

Despite the fact that the total number of Lyme disease - sick persons is small with no death cases reported, the understanding of a true epidemiologi$\mathrm{cal}$ and epizootiological situation of this disease is a prerequisite for organized planning and implementation of measures for suppression of the disease and adequate Public health protection.

For the purpose of determining the actual situation concerning Lyme disease in the region, further studies in the field of infection prevalence in ticks 
and determination of entomological risk index are needed to identify the season and region(s) with infected vectors that represent potential risk for the occurrence of infection or disease in humans or animals.

\section{ACKNOWLEDGMENTS}

We wish to thank for the contribution to this work to: Arpad Pacarek Veterinary Clinic "Anidok" Mali Iđoš,; Slobodan Stevanov Veterinary Clinic "Panvet" Subotica; Mario Tikvicki Veterinary Clinic "Veterinar" Subotica; Stojan Radaković Veterinary Clinic "Ekosvet” Subotica; all from Republic of Serbia.

\section{REFERENCES}

1. Aguero-Rosenfeld M.E., Wang G., Schwartz I., Wormser G.P.: Diagnosis of Lyme borreliosis. Clinical Microbiology Reviews, 18, 484-509, 2005.

2. Cutler S.J., Rudenko N., Golovchenko M., Cramaro W.J., Kirpach J., Savic S., Christova I., Amaro A.: Diagnosing Borreliosis. Vector Borne Zoonotic Diseases, 17, 1, 2-11, 2017.

3. Gray J.S.: The ecology of ticks transmitting Lyme borreliosis. Experimental and Applied Acarology, 22, 249-258, 1998.

4. Infectious diseases in Province of Vojvodina in 2015, annual report, Novi Sad, Institute for Public Health of Vojvodina, 2016 - Zarazne bolesti u AP Vojvodini 2015. godina, godišnji izveštaj. Novi Sad: Institut za javno zdravlje Vojvodine, 2016.

5. Margos G., Gatewood A.G., Aanensen D.M., Hanincová K., Terekhova D., Vollmer S.A., Cornet M., Piesman J., Donaghy M., Bormane A., Hurn M.A., Feil E.J., Fish D., Casjens S., Wormser G.P., Schwartz I., Kurtenbach K.: MLST of housekeeping genes captures geographic population structure and suggests a European origin of Borreliaburgdorferi. Proceedings of the National Academy of Sciences, 105, 8730-8735, 2008.

6. Mladenović Lj.: Epidemiološki aspekti lajmske bolesti na teritoriji grada Beograda (Doktorska disertacija). Niš: Medicinski fakultet u Nišu, 2014.

7. Orloski A.K., Hayes B.E., Kampbell G.L., Dennis D.T.: Surveillance for Lyme Disease - United States, 1992-1998. MMVR Medicine Meets Virtual Reality, 49, SS03, 1-1, 2000.

8. Pavlović N.: Lajmska bolest-rizik, obolevanje i sprečavanje. Beograd: Gradski zavod za javno zdravlje, 2006.

9. Rizzoli A., Hauffe H.C., Carpi G., Vourch G.I., Neteler M., Rosà R.: Lyme borreliosis in Europe. Euro Surveillance, 16, 27, 2011. 
10. Ropac D., Holubek M., Grgić V., Stašević I.: Lymeska bolest na području Bjelovarsko-bilogorske županije - zanemariva ili zanemarena bolest. Croatian Journal of Infection, 33, 1, 21-26, 2013.

11. Steere A.C., Coburn J., Glickstein L.: The emergence of Lyme disease. The Journal of Clinical Investigation, 113, 1093-1101, 2004.

Primljeno: 28.11.2017.

Odobreno: 29.12.2017. 